\title{
Correction to: Qualitative study: burden of menopause-associated vasomotor symptoms (VMS) and validation of PROMIS sleep disturbance and sleep-related impairment measures for assessment of VMS impact on sleep
}

Marci English ${ }^{1 *}$, Boyka Stoykova ${ }^{2}$, Christina Slota ${ }^{3}$, Lynda Doward $^{4}$, Emad Siddiqui $^{2}$, Rebecca Crawford ${ }^{4}$ and Dana DiBenedetti ${ }^{3}$

Correction to: Journal of Patient-Reported Outcomes 5, 37 (2021).

https://doi.org/10.1186/s41687-021-00289-y

After publication of the original article [1], an error was identified in both Tabl1 and 2.

The below footnote should be added:

"Reproduced with permission from Health Measures (00030669). PROMIS measures are available at: http:// www.healthmeasures.net/explore-measurement-systems/ promis/obtain-administer-measures".

The original article has been corrected.

\section{Author details}

${ }^{1}$ Astellas Pharma Inc., Pharma Global Development, Astellas Way, Northbrook, IL 60062-6111, USA. ${ }^{2}$ Astellas Pharma Inc., Chertsey, Surrey, UK. ${ }^{3}$ RTI Health Solutions, Patient-Centered Outcomes Assessment Group, Research Triangle Park, NC, USA. ${ }^{4}$ RTI Health Solutions, Manchester, UK.

Published online: 01 June 2021

\section{Reference}

1. English, et al. (2021). Qualitative study: Burden of menopause-associated vasomotor symptoms (VMS) and validation of PROMIS sleep disturbance and sleep-related impairment measures for assessment of VMS impact on sleep. Journal of PatientReported Outcomes, 5, 37. https:/doi.org/10.1186/s41687-021-00289-y.

The original article can be found online at https://doi.org/10.1186/s41687 021-00289-y.

* Correspondence: marci.english@astellas.com

'Astellas Pharma Inc., Pharma Global Development, Astellas Way, Northbrook, IL 60062-6111, USA

Full list of author information is available at the end of the article

\section{Springer Open}

(-) The Author(s). 2021 Open Access This article is licensed under a Creative Commons Attribution 4.0 International License, which permits use, sharing, adaptation, distribution and reproduction in any medium or format, as long as you give appropriate credit to the original author(s) and the source, provide a link to the Creative Commons licence, and indicate if changes were made. The images or other third party material in this article are included in the article's Creative Commons licence, unless indicated otherwise in a credit line to the material. If material is not included in the article's Creative Commons licence and your intended use is not permitted by statutory regulation or exceeds the permitted use, you will need to obtain permission directly from the copyright holder. To view a copy of this licence, visit http://creativecommons.org/licenses/by/4.0/. 